\title{
The association between PON1 gene polymorphisms (Q192R and L55M) and nephrotic syndrome in Iraqi children
}

\author{
Raghad J. Ali ${ }^{1}$, Rayah S. Baban ${ }^{2}$ and Shatha H. Ali ${ }^{3}$ \\ ${ }^{1}$ Baghdad Medical City, Iraqi Ministry of Health, Baghdad, Iraq \\ ${ }^{2}$ Department of Chemistry and Biochemistry, College of Medicine, Al-Nahrain University, Baghdad, Iraq \\ ${ }^{3}$ Department of Pediatrics, College of Medicine, Al-Nahrain University, Baghdad, Iraq
}

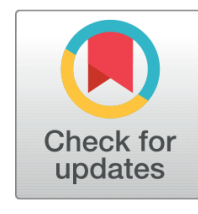

Received 14-06-2021
Revised 15-07-2021
Accepted 19-07-2021
Published 21-07-2021

Corresponding Author

Raghad J. Ali

raghad78r@gmail.com

Baghdad Medical City, Ministry of Health, Baghdad, Iraq

DOI https://doi.org/10.47419/ bjbabs.v2i03.55

\section{Pages: 120-132}

Distributed under the terms of the Creative Commons

Attribution-NonCommercial 4.0 International (CC-BY-NC 4.0), which permits use for any non-commercial purpose, distribution, and reproduction in any medium, provided that the original work is properly cited.

Copyright: (C) 2021 Raghad J. Ali, Rayah S. Baban, Shatha H. Ali

\section{OPEN ACCESS}

\section{ABSTRACT}

Background: The role of paraoxonase 1 enzyme (PON1) and its single nucleotide polymorphisms (SNPs) in children with nephrotic syndrome (NS) has been reported previously in different ethnic and racial groups with divergent results. The human PON1 gene contains two coding region polymorphisms leading to two different PON1 isoforms.

Objectives: The aim of the present study was to find out the association between the PON1 (Q192R and L55M) polymorphisms and their relation with serum PON1 activity as well as lipid profile tests (total cholesterol, TC; triglycerides, TG; high-density lipoprotein cholesterol, HDL-c; and low-density lipoprotein cholesterol, LDL-c) in children with NS.

Methods: This study included a total of 80 participants ( 40 with NS in the age group of 2-14 years and 40 age and sex-matched healthy controls). The PON1 enzyme activity and lipid profile tests were measured in serum samples of all included participants. The PON1 genotype was determined by PCR-restriction enzyme fragment length polymorphism (PCR-RFLP) for both PON1 alleles (192 and 55) SNPs.

Results: Our findings showed that the mean levels of lipid profile tests (TC, TG, LDL-c) were significantly increased in patients when compared with healthy controls $(p<0.05)$, while the HDL-c concentration was significantly decreased in patients than that of controls. Also, the patients had significantly lower concentrations of PON1 when compared with the controls regardless of the genotype Q192R and L55M polymorphisms. Moreover, the homozygous RR genotype for PON1 SNP 192 and MM homozygous genotype for PON1 SNP 55 were significantly frequent in patients when compared with the controls.

Conclusions: Our results support that the presence of the homozygous RR genotype for PON1 SNP 192 and MM homozygous genotype for PON1 SNP 55 were significantly higher in patients compared with the controls.

Keywords fluorescence assay, L55M, nephrotic syndrome, paraoxonase 1, Q192R, SNP 


\section{INTRODUCTION}

The most common glomerular disorder in children is nephrotic syndrome (NS), which associated with heavy nephrotic-range proteinuria (NRP: $>40 \mathrm{mg} / \mathrm{h} / \mathrm{m}^{2}$ or $>50 \mathrm{mg} / \mathrm{kg} /-$ day or protein/creatinine ratio $>0.2 \mathrm{~g} / \mathrm{mmol}) .{ }^{1-3}$ The paraoxonase 1 (PON1) is an enzyme involved in lipid metabolism. It is bound to high-density lipoprotein (HDL) and acts as an antioxidant for the low-density lipoproteins (LDL), by hydrolyzing lipid peroxides, thus; it prevents LDL oxidation and inhibits atherogenesis. ${ }^{4,5}$ PON1 has a vital role in free radical scavenging system, particularly, in detoxification of wide range of substrates such as organophosphate compounds and carcinogenic lipid soluble radicals resultant from lipid peroxidation. ${ }^{6}$ It catalyzes the hydrolysis of multiple compounds such as arylesterase, lactones and hydroxiperoxides. ${ }^{6}$ In its coding region, there are two common polymorphisms at positions 55 and 192 which is more widely recognized than $55 .^{7,8}$ The differences between them are related to their affinity and catalytic activities toward many substrates. ${ }^{7,8}$ The Q192R polymorphism or the missense mutation at position 192 (rs662) in exon 6 of the PON1 gene is one of the most important widely studied polymorphisms which involve the substitution of amino acid glutamine (Q) to arginine (R) at position 192 (Q192R). ${ }^{9}$ A substitution that has the effect of altering catalytic efficiency. ${ }^{8}$ In L55M polymorphism, the codon change from TTG to ATG in exon 3 of PON1 gene results in the substitution of amino acid leucine to methionine at position $55 .^{10}$

However, the association between PON1 polymorphisms (Q192R and L55M) and NS is not yet fully understood, particularly, in Iraqi patients with NS. Thus, we aimed here to determine the the association between PON1 polymorphisms (Q192R and L55M) and NS among Iraqi children with NS.

\section{MATERIALS AND METHODS Study design and subjects}

This is a case-control study was conducted at Al-Imamain Al-Kadhimain Medical City, Biochemistry Department and Pediatric Department at the College of Medicine, Al-Nahrain University during the period from January to November 2019. Eighty participants were included and divided into two groups (40 were patients with NS in active phase as newly diagnosed or old cases with acute relapse, and 40 age-and sex-matched healthy controls), the age range was 2-14 years. The patients were diagnosed, treated, and followed up in the Pediatric Nephrology Unit at Al-Imamain Kadhimain Medical City, and Baghdad Welfare Teaching Hospital in Medical City of Baghdad. Control subjects were evaluated by a consultant Pediatric Nephrologist to ensure the absence of any renal disease. A well-designed questionnaire was filled with each participant's details after direct interview with the parents of patients and control subjects. The doctors were also involved before collecting the blood sample. Data collected included age, sex, age of onset of NS, type of NS according to steroid responsiveness and frequency of relapses. Some information 
was taken from the hospital records as well. Body weight and height measurements was perfumed to all study participants.

Diagnosis of NS was made according to the following criteria: 1) Relapse: heavy proteinuria $>40 \mathrm{mg} / \mathrm{h} / \mathrm{m}^{2}$ or $>50 \mathrm{mg} / \mathrm{kg} /$ day, Albustix $\geq+++$ for 3 consecutive days after having been in remission. 2) Frequent relapses: 2 or more relapses within 6 months of initial response or 4 or more relapses within a period of 1 year, hypo-albuminemia $<2.5 \mathrm{~g} / \mathrm{dl}$, edema and hyperlipidemia. ${ }^{1,2}$ Patients with other renal disease, liver disease, diabetes, urolethiasis and malnourished children as well as patients with familial hyperlipidemia were excluded from the study.

\section{Blood sampling and DNA isolation}

A $5 \mathrm{ml}$ venous blood sample was collected at morning (8:30 a.m.) from each participant, and divided into two parts ( $2 \mathrm{ml}$ in EDTA and $3 \mathrm{ml}$ in plain tube). The whole blood samples, dispensed in tube containing EDTA, were mixed gently and placed in a cool-box under aseptic condition. Then, they were stored in the freezer at $-80{ }^{\circ} \mathrm{C}$ until further processing for DNA extraction. DNA extracted from blood using spin DNA extraction kit (Cat. No.: 17045, iNtRON Biotechnology). ${ }^{11}$ Separately, samples placed plain tubes were centrifuged at $3000 \mathrm{rpm}$ for $10 \mathrm{~min}$ to obtain serum samples and the sera were then divided into two portions, first one kept in Eppendorf tubes in $-80^{\circ} \mathrm{C}$ until estimation for PON1 activity and the other portion for measuring lipid profile tests (TC, TG, HDL-c, LDL-c), blood glucose, blood urea, serum creatinine, total serum protein and serum albumin at the same day.

\section{Biochemical analyses General tests}

Fasting blood glucose, lipid profile tests, blood urea, serum creatinine, total serum protein and serum albumin were determined using Auto-analyzer (Siemens, Japan).

\section{Analysis of PON1 activity}

PON1 activity was tested by fluorescence assay kit (ab241044, Abcam, Austria) that enables rapid measurement of PON1 activity, utilizing a fluorogenic substrate that is converted into a highly fluorescent product $(\mathrm{Ex} / \mathrm{Em}=368 / 460 \mathrm{~nm})$. Using Glow max reader (Promega Co., France). The assay is simple to perform, high-throughput adaptable and can detect a minimum of $2.0 \mu \mathrm{U}$ PON1 activity with a sample volume of $5 \mu \mathrm{L}$. This ensures dramatically greater sensitivity than UV or colorimetric assays and eliminates the need for dangerous toxic substrates. 


\section{Molecular analyses PONI genotyping}

The genotypes for PON1 gene polymorphisms (192 and 55) were determined by using RFLP, PCR-based technique, described earlier. ${ }^{11}$ The primer used to amplify a fragment with the size of 113bp for PON1 192 polymorphism: sense primer 5'-TAT TGT TGC TGT GGG ACC TGA G-3' and anti-sense primer 5'-CAC GCT AAA CCC AAA TAC ATC TC-3' which encompass the 192 polymorphic region. While, to amplify a fragment with the size of $170 \mathrm{bp}$ for the 55 polymorphism, sense primer 5'-GAA GAG TGA TGT ATA GCC CCA G-3' and antisense primer 5'-TTT ATT CCA GAG CTA ATG AAA GCC -3' were used. The PCR mixture contained: premix mixture compnents (i-Taq DNA polymerase, dNTP mixture, reaction buffer and gel loading buffer). Then, we took PCR premix $(5 \mu \mathrm{l})$, forward primer $(1 \mu \mathrm{l})$, reverse primer $(1 \mu \mathrm{l})$, DNA $(1.5 \mu \mathrm{l})$, distill water $(16.5 \mu \mathrm{l})$ and the final volume $(25 \mu \mathrm{l})$. The PCR conditions included a denaturation, annealing and extension according to PCR technology by Henry Erlich (2015). ${ }^{11}$

\section{Gel electrophoresis after DNA isolation, PCR, and PCR-RFLP PON1 (55) SNP - Agarose gel electrophoresis}

Electrophoresis has been done to confirm the success of the DNA isolation process and to assess the results of the PCR amplification as well as PCR-RFLP, visually. Agarose gel electrophoresis was used to analyze the presence of the extracted DNA and detected the amplified PCR product, as well as analysis PCR-restriction fragment length polymorphism (RFLP) were performed as follows. ${ }^{12}$ The PCR products with length of (170bp) were restricted by using Hsp19211 enzyme (New England Biolabs, UK) to determine PON1 (55) SNP. The Allel-L (leucine) did not contain Hsp site and visualized as one band 170bp, while allel-M (methionine) contained $H s p$ site resulting in two bands (126 and 44bp) fragments, on other hand the restricting enzyme cleaved the PCR products with subjects with heterozygous L-M genotype into three bands (170,126 and $44 \mathrm{bp})$ fragments as shown in Figure 1.

\section{PON1 (192) SNP — Polyacrylamide gel electrophoresis}

PON1 192 SNP genotyping was performed by PCR-RFLP. The PCR products 113bp were restricted by using Bsp1 enzyme (New England Biolabs, UK) to determine PON1 192 SNP. After PCR, The reaction was performed as follows: $10 \mu \mathrm{l}$ a total volume, incubation at $37^{\circ} \mathrm{C}$ for $40 \mathrm{~min}$, PCR products with length of $113 \mathrm{bp}$ was treated with the Bsp 1 and the digested fragments were electrophoresed on polyacrylamide gel mixed with red stain for $90 \mathrm{~min}, 70 \mathrm{v}$ and the band was calculated alongside (50-1000bp) DNA ladder for genotyping of studied samples. Cases which have only QQ genotype was not digested and showed only 113bp fragments, while the RR genotype indicates digestion to 23 and $90 \mathrm{bp}$ fragments, but; the 


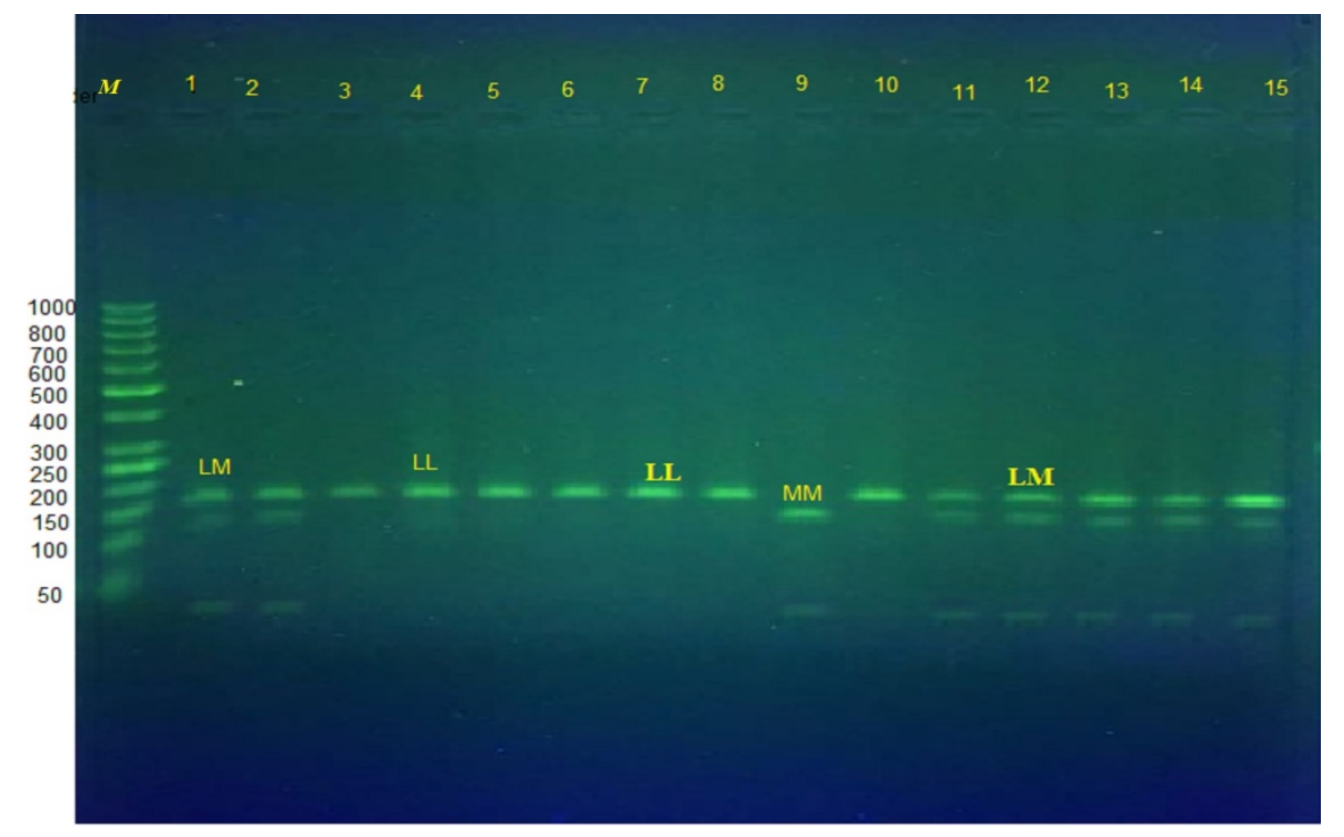

Figure 1 Determination of PON1 polymorphism (L55M) by PCR-RFLP digestion with Hsp19211 restriction enzyme (2.5\% agarose gel). Homozygous LL: genotype $170 b p$ lines $3,4,5,10$; homozygous MM: genotype 126+44bp lines 9; and heterozygous LM: genotype 170+126+44bp lines 1,2,11,15. M: DNA molecular marker 50bp size. By red stain stained bands in the gel.

QR genotype refer to 90, 23, 113bp fragments (Figure 2).

\section{Statistical analyses}

The data was examined for normality, homogeneity and normal distribution, mean $\pm \mathrm{SE}$ of mean by using the SPSS v. 26.0 (IBM, USA). ${ }^{13}$ The probability also examined by using student $\mathrm{t}$-test and one way ANOVA test. For non-parametric data, Pearson's chi-square test was used to calculate the probability and the $\mathrm{p}$ value was considered significant if it is below 0.05 . For genotyping and allele frequency, the odds ratio, $95 \%$ confidence interval and Fisher's exact probability calculated by Windpipe version $11.65 .{ }^{14}$ Online Hardy-Weinberg calculator ${ }^{15}$ was also used for genotyping and allele frequency calculations.

\section{RESULTS}

\section{Anthropometric characteristics}

Demographic parameters of both, patients and controls, are shown in Table 1. There was no statistical differences in the sex distribution $(p=0.994)$ and mean age between the two groups; both the groups were comparable. 




Figure 2 Determination of PON1 polymorphism (Q192R) by PCR-RFLP digestion with Bsp1 restriction enzyme (DNA polyacrylamide gel electrophoresis pattern of 113bp PCR product). Homozygous QQ genotype: 113bp; homozygous RR genotype: 90+23bp; heterozygous QR genotype: 113+90+23bp.

Table 1 Anthropocentric characteristics of study participants

\begin{tabular}{llll} 
& Patients $(\mathbf{n}=\mathbf{4 0})$ & Controls $(\mathbf{n}=\mathbf{4 0})$ & $\boldsymbol{P}$ \\
Age (year) & $7.14 \pm 0.57$ & $7.20 \pm 0.55$ & 0.994 \\
\hline
\end{tabular}

\section{Biochemical parameters}

Biochemical parameters in serum of patients and controls are shown in Table 2. The mean of albumin levels was significantly lower in patients $(p<0.05)$, whereas TC, TG, LDL$c$, and HDL-c were significantly higher in patients when compared to controls $(p<0.0001)$. The levels of PON1 enzyme are significantly dropped in NS patients when compared to controls $(p<0.0001)$.

\section{Molecular analyses}

The PON1 gene (55) SNP was found to be informative in our study groups. In the study the results of genotypes and allele frequency are shown in the Table 3, which illustrates that allele $\mathrm{L}$ is more observed in both control and patients (70\% and 60\%, respectively) than 
Table 2 The comparison of the studied parameters levels between control and nephrotic syndrome patients

\begin{tabular}{llll} 
& Patients $(\mathbf{n}=\mathbf{4 0})$ & Controls $(\mathbf{n}=\mathbf{4 0})$ & $P$ \\
BMI $\left(\mathrm{Kg} / \mathrm{m}^{2}\right)$ & $23.61 \pm 1.39$ & $18.60 \pm 0.48$ & 0.010 \\
Blood urea $(\mathrm{mg} / \mathrm{dl})$ & $43.52 \pm 6.69$ & $27.49 \pm 0.56$ & 0.083 \\
Creatinine $(\mathrm{mg} / \mathrm{dl})$ & $1.56 \pm 0.89$ & $0.79 \pm 0.02$ & 0.571 \\
Albumin $(\mathrm{mg} / \mathrm{dl})$ & $1.33 \pm 0.12$ & $4.12 \pm 0.06$ & 0.0001 \\
TC $(\mathrm{mg} / \mathrm{dl})$ & $382.93 \pm 19.82$ & $163.12 \pm 2.66$ & 0.0001 \\
TG $(\mathrm{mg} / \mathrm{dl})$ & $333.80 \pm 24.49$ & $132.93 \pm 2.09$ & 0.0001 \\
HDL-c $(\mathrm{mg} / \mathrm{dl})$ & $39.80 \pm 1.28$ & $62.61 \pm 2.25$ & 0.0001 \\
LDL-c (mg/dl) & $201.25 \pm 13.62$ & $75.39 \pm 2.69$ & 0.0001 \\
Serum paraxonase & 1 & $327.54 \pm 6.45$ & 0.0001 \\
$(\mu \mathrm{U} / \mathrm{ml})$ & & & \\
\hline
\end{tabular}

the allele $\mathrm{M}(30 \%$ and $40 \%$, respectively). While the frequency of the genotype showed the higher frequency of LL genotype in control 19/40 (47.5\%) than patients 15/40 (37.5\%) and this difference was insignificant $(p=0.4$ ) while the heterozygote (LM) genotype showed insignificantly $(p=1.0)$ higher frequency in control 19/40 (47.5\%) than in patients $18 / 40$ (45\%). Finally, the homozygous (MM) genotype showed insignificantly $(p=0.514)$ higher frequency in patients $7 / 40(17.5 \%)$ than in controls $2 / 40(5 \%)$.

Table 3 PON1 gene (55) SNP frequency between the studied groups

\begin{tabular}{|c|c|c|c|c|c|c|c|}
\hline & \multicolumn{2}{|c|}{ Patients n(\%) } & \multicolumn{2}{|c|}{ Control n(\%) } & \multirow[t]{2}{*}{$\chi^{2}$} & \multirow{2}{*}{$\begin{array}{l}\text { OR }(95 \% \\
\text { CI })\end{array}$} & \multirow[t]{2}{*}{$P^{\dagger}$} \\
\hline & Observed & Expected & Observed & Expected & & & \\
\hline \multicolumn{8}{|l|}{ Alleles } \\
\hline $\mathrm{L}$ & 0.60 & & 0.70 & & & & \\
\hline M & 0.40 & & 0.30 & & & & \\
\hline \multicolumn{8}{|l|}{ Genotypes } \\
\hline LL & $15(37.5)$ & $14.4(36.0)$ & $19(47.5)$ & $20.3(50.7)$ & 0.818 & $\begin{array}{l}0.66(0.25- \\
1.77)\end{array}$ & 0.498 \\
\hline $\mathrm{LM}$ & $18(45.0)$ & $19.2(48.0)$ & $19(47.5)$ & $16.4(41)$ & 0.050 & $\begin{array}{l}0.9(0.34- \\
2.38)\end{array}$ & 1.000 \\
\hline MM & $7(17.5)$ & $6.4(16.0)$ & $2(5)$ & $3.3(8.3)$ & 3.130 & $\begin{array}{l}4.03(0.69- \\
41.7)\end{array}$ & 0.514 \\
\hline Total & $40(100.0)$ & $40(100.0)$ & $40(100.0)$ & $40(100.0)$ & & & \\
\hline$P$-HWE & 0.6926 & & 0.5501 & & & & \\
\hline
\end{tabular}

${ }^{\dagger}$, Fisher's exact probability (2-tailed); HWE, Hardy-Weinberg Equilibrium

In this study, the distributions of PON1 192 genotypes and allele frequencies are shown in the Table 6, which illustrates that allele $\mathrm{Q}$ is more observed in patients (55\%) than the allele R (45\%). While the frequency of the genotype showed the higher frequency of $\mathrm{Q}$ genotype with control (80\%) than in patients (55\%). The R allele frequency is more observed in patients (45\%) than control (20\%), SNP 192 genotypes effect on biochemical parameters and lipid profile are shown in the Table 5. 


\begin{tabular}{|c|c|c|c|c|}
\hline Parameters & Genotype & Patients & Control & $P$ \\
\hline \multirow[t]{3}{*}{ BMI $\left(\mathrm{kg} / \mathrm{m}^{2}\right)$} & LL & $25.22 \pm 2.27$ & $18.94 \pm 0.93$ & 0.003 \\
\hline & LM & $21.89 \pm 1.53$ & $17.97 \pm 0.36$ & 0.088 \\
\hline & MM & $21.60 \pm 4.34^{a}$ & $20.41 \pm 1.88$ & 0.814 \\
\hline \multirow[t]{3}{*}{ Blood urea $(\mathrm{mg} / \mathrm{dl})$} & LL & $46.52 \pm 11.58^{a}$ & $27.42 \pm 0.84$ & 0.051 \\
\hline & LM & $38.05 \pm 6.22$ & $27.26 \pm 0.73$ & 0.308 \\
\hline & MM & $48.25 \pm 19.81$ & $29.33 \pm 0.56$ & 0.419 \\
\hline \multirow[t]{3}{*}{ Creatinine $(\mathrm{mg} / \mathrm{dl})$} & $\mathrm{LL}$ & $0.79 \pm 0.10$ & $0.81 \pm 0.04$ & 0.990 \\
\hline & LM & $0.54 \pm 0.05$ & $0.79 \pm 0.04$ & 0.830 \\
\hline & MM & $0.98 \pm 0.88$ & $0.73 \pm 0.07$ & 0.202 \\
\hline \multirow[t]{3}{*}{ Abumin (mg/dl) } & LL & $1.22 \pm 0.11$ & $4.18 \pm 0.10$ & 0.0001 \\
\hline & LM & $1.41 \pm 0.23$ & $4.14 \pm 0.08$ & 0.00001 \\
\hline & MM & $1.58 \pm 0.62$ & $3.60 \pm 0.06$ & 0.000025 \\
\hline \multirow[t]{3}{*}{$\mathrm{TC}(\mathrm{mg} / \mathrm{dl})$} & $\mathrm{LL}$ & $364.52 \pm 23.34$ & $163.68 \pm 4.14$ & 0.00001 \\
\hline & LM & $410.67 \pm 38.56$ & $161.84 \pm 3.85$ & 0.00001 \\
\hline & $\mathrm{MM}$ & $375.50 \pm 66.43$ & $167.67 \pm 10.11$ & 0.003 \\
\hline \multirow[t]{3}{*}{$\mathrm{TG}(\mathrm{mg} / \mathrm{dl})$} & LL & $340.57 \pm 27.27$ & $133.90 \pm 2.62$ & 0.00001 \\
\hline & $\mathrm{LM}$ & $353.73 \pm 50.34$ & $132.74 \pm 3.66$ & 0.00001 \\
\hline & $\mathrm{MM}$ & $223.50 \pm 54.38$ & $128.0 \pm 4.62$ & 0.00254 \\
\hline \multirow[t]{3}{*}{ HDL-c (mg/dl) } & LL & $39.86 \pm 1.75$ & $61.26 \pm 3.32$ & 0.00001 \\
\hline & LM & $39.47 \pm 2.33$ & $62.68 \pm 3.38$ & 0.00001 \\
\hline & MM & $40.75 \pm 3.28$ & $70.67 \pm 7.88$ & 0.00001 \\
\hline \multirow[t]{3}{*}{ LDL-c (mg/dl) } & LL & $171.86 \pm 8.46$ & $73.37 \pm 4.11$ & 0.00001 \\
\hline & LM & $224.33 \pm 27.70$ & $77.42 \pm 4.04$ & 0.00001 \\
\hline & MM & $269.0 \pm 66.97$ & $75.33 \pm 7.86$ & 0.00001 \\
\hline
\end{tabular}

Table 5 PON1 gene SNP 192 frequency between the studied groups

\begin{tabular}{|c|c|c|c|c|c|c|c|}
\hline & \multicolumn{2}{|c|}{ Patients n(\%) } & \multicolumn{2}{|c|}{ Control n(\%) } & \multirow[t]{2}{*}{$\chi^{2}$} & \multirow[t]{2}{*}{ OR (95\% CI) } & \multirow[t]{2}{*}{$\boldsymbol{P}^{\dagger}$} \\
\hline & Observed & Expected & Observed & Expected & & & \\
\hline \multicolumn{8}{|l|}{ Allels } \\
\hline Q & 0.55 & & 0.80 & & & & \\
\hline $\mathrm{R}$ & 0.45 & & 0.20 & & & & \\
\hline \multicolumn{8}{|c|}{ Genotypes } \\
\hline QQ & $18(0.45)$ & 12.1(0.30\% & $27(0.67)$ & 25.6(0.64\%) & 4.114 & $0.39(0.10-0.99)$ & 0.0761 \\
\hline QR & $8(0.20)$ & 19.8(0.50\%) & $10(0.25)$ & 12.8(0.32\%, & 0.287 & $0.75(0.22-2.24)$ & 0.790 \\
\hline $\mathrm{RR}$ & $14(0.35)$ & $8.1(0.20 \%)$ & $3(0.08)$ & $1.6(0.04 \%)$ & 9.038 & $6.64(0.52-7.0)$ & 0.005 \\
\hline Total & $40(100.0)$ & $40(100.0)$ & $40(100.0)$ & $40(100.0)$ & & & \\
\hline
\end{tabular}

${ }^{\dagger}$, Fisher's exact probability (2-tailed) 


\begin{tabular}{|c|c|c|c|c|}
\hline Parameters & Genotype & Patients & Control & $P$ \\
\hline \multirow[t]{3}{*}{ BMI $\left(\mathrm{kg} / \mathrm{m}^{2}\right)$} & QQ & $22.39 \pm 1.42^{A}$ & $18.02 \pm 0.38^{A}$ & 0.371 \\
\hline & QR & $25.61 \pm 2.68^{A}$ & $19.79 \pm 1.15^{A}$ & 0.128 \\
\hline & $\mathrm{RR}$ & $21.07 \pm 2.34^{A}$ & $17.34 \pm 0.53^{A}$ & 0.944 \\
\hline \multirow[t]{3}{*}{ Blood urea (mg/dl) } & QQ & $41.27 \pm 5.49^{A}$ & $27.33 \pm 0.81^{A}$ & 0.803 \\
\hline & QR & $39.43 \pm 12.42^{A}$ & $28.20 \pm 0.95^{A}$ & 0.896 \\
\hline & $\mathrm{RR}$ & $58.86 \pm 18.47^{A}$ & $26.0 \pm 1.47^{A}$ & 0.520 \\
\hline \multirow[t]{3}{*}{ Creatinine (mg/dl) } & QQ & $2.98 \pm 2.36^{A}$ & $0.78 \pm 0.04^{A}$ & 0.578 \\
\hline & QR & $0.73 \pm 0.12^{A}$ & $0.84 \pm 0.03^{A}$ & 1.0 \\
\hline & $\mathrm{RR}$ & $0.61 \pm 0.13^{A}$ & $0.8 \pm 0.05^{A}$ & 1.0 \\
\hline \multirow[t]{3}{*}{ Abumin (mg/dl) } & QQ & $1.24 \pm 0.16^{A}$ & $4.17 \pm 0.09^{A}$ & 0.00001 \\
\hline & QR & $1.35 \pm 0.17^{A}$ & $4.03 \pm 0.10^{A}$ & 0.00001 \\
\hline & $\mathrm{RR}$ & $1.47 \pm 0.41^{A}$ & $4.28 \pm 0.11^{A}$ & 0.00001 \\
\hline \multirow[t]{3}{*}{ TC (mg/dl) } & QQ & $410.73 \pm 32.79^{A}$ & $165.14 \pm 3.55^{A}$ & 0.00001 \\
\hline & QR & $333.50 \pm 19.02^{B}$ & $163.80 \pm 4.62^{A}$ & 0.000003 \\
\hline & $\mathrm{RR}$ & $450.43 \pm 67.07^{A B}$ & $155.0 \pm 9.57^{A}$ & 0.000007 \\
\hline \multirow[t]{3}{*}{$\mathrm{TG}(\mathrm{mg} / \mathrm{dl})$} & QQ & $364.47 \pm 36.87^{A}$ & $134.33 \pm 3.29^{A}$ & 0.00003 \\
\hline & QR & $287.78 \pm 20.09^{A}$ & $133.20 \pm 1.94^{A}$ & 0.00001 \\
\hline & $\mathrm{RR}$ & $386.43 \pm 104.11^{A}$ & $132.75 \pm 7.65^{A}$ & 0.00001 \\
\hline \multirow[t]{3}{*}{ HDL-c (mg/dl) } & QQ & $41.73 \pm 2.23^{A}$ & $60.76 \pm 2.98^{A}$ & 0.000065 \\
\hline & QR & $38.33 \pm 1.49^{A}$ & $68.67 \pm 2.78^{A}$ & 0.00008 \\
\hline & $\mathrm{RR}$ & $39.43 \pm 4.17^{A}$ & $53.0 \pm 12.05^{B}$ & 0.00001 \\
\hline \multirow[t]{3}{*}{ LDL-c (mg/dl) } & QQ & $202.67 \pm 21.47^{A}$ & $73.38 \pm 3.42^{A}$ & 0.00001 \\
\hline & QR & $169.89 \pm 15.15^{A}$ & $78.40 \pm 4.79^{A}$ & 0.00026 \\
\hline & $\mathrm{RR}$ & $278.86 \pm 38.56^{A}$ & $74.0 \pm 12.66^{A}$ & 0.000003 \\
\hline
\end{tabular}

The vertical comparison was done by Duncan test; the similar letters referred to a non-significant difference while the different letters referred to a significant difference.

\section{PON1 SNPs and serum PON1}

Effect of PON1 SNP 55 on serum paraxonase 1 activity are presented in Table 7, and notably lower enzyme activity observed with $\mathrm{M}$ allele in NS patients compared with controls. The higher activity was seen with the LL genotype $(146.57 \pm 5.4 \mu \mathrm{U} / \mathrm{ml})$ followed by the LM genotype $(114.53 \pm 5.95 \mu \mathrm{U} / \mathrm{ml})$ and the lowest activity recorded by the MM genotype $(82.0 \pm 3.37 \mu \mathrm{U} / \mathrm{ml})$. On other hand, the effect of the PON1 SNP 192 on activity of the paraoxonase 1 enzyme in Table 8 showed significantly lower enzyme activity $(p<0.0001)$ with RR genotype in patients $(115.86 \pm 9.89 \mu \mathrm{U} / \mathrm{ml})$ than in controls $(316.75 \pm 0.32 \mu \mathrm{U} / \mathrm{ml})$.

\section{DISCUSSION}

In the present study, lipid tests (TC, TG, LDL-c) were higher in patients than in control group, while serum albumin, HDL-c and serum paraxonase activity are markedly dropped in patients' group as compared with controls (Table 2), this is in accordance with a number 
Table 7 Comparison of the serum PON1 levels $(\mu \mathrm{U} / \mathrm{ml})$ in patients and controls within the three genotypes of PON1 55 SNP

\begin{tabular}{llll} 
Genotypes & Patients group & Control group & $\boldsymbol{P}$ \\
LL & $146.57 \pm 5.41^{A}$ & $337.67 \pm 52.75^{A}$ & 0.00001 \\
LM & $114.53 \pm 5.95^{B}$ & $324.84 \pm 7.42^{A}$ & 0.00001 \\
MM & $82.0 \pm 3.37^{B}$ & $328.63 \pm 9.70^{A}$ & 0.00001 \\
\hline
\end{tabular}

The vertical comparison was done by Duncan test; the similar letters referred to a non-significant difference while the different letters referred to a significant difference.

Table 8 Comparison of the serum PON1 levels $(\mu \mathrm{U} / \mathrm{ml})$ in patients and controls within the three genotypes of PON1 192 SNP

\begin{tabular}{llll} 
Genotypes & Patients $(\mathbf{n}=\mathbf{4 0})$ & Controls $(\mathbf{n}=\mathbf{4 0})$ & $\boldsymbol{P}$ \\
QQ & $133.0 \pm 8.09^{A}$ & $325.81 \pm 9.40^{A}$ & 0.00001 \\
QR & $128.78 \pm 7.88^{A}$ & $331.87 \pm 10.92^{A}$ & 0.00001 \\
RR & $115.86 \pm 9.89^{A}$ & $316.75 \pm 20.32^{A}$ & 0.00001 \\
\hline
\end{tabular}

The vertical comparison was done by Duncan test; the similar letters referred to a non-significant difference while the different letters referred to a significant difference

of previous reports that have highlighted the role of PON1 in various diseases associated with hyperlipidemia such as coronary heart disease, ${ }^{16}$ insulin dependent diabetes mellitus, ${ }^{17}$ strokes and atherosclerosis ${ }^{18}$. Hyperlipidemia is a well-known biochemical component of the idiopathic nephrotic syndrome (INS), both during relapses and remissions of the disease. ${ }^{19,20}$ Abnormal lipid profile is believed to be a precursor for glomerulosclerosis with subsequent kidney failure. ${ }^{21,22}$ This study done to find out the association between PON1 SNPs (192 and 55), among Iraqis children with NS, and the enzyme activity of PON1; which found to be decreased in all patients group with MM homozygous allele. Among the studied groups, PON1 SNP 55 are more frequent in patients (OR: 4.03, Tables $3 \& 4$ ) who have the lowest PON1 levels (Table 7); which may carry a high risk when compared with controls.

In accordance with other studies, Biyikli et. $\mathrm{al}^{23}$ observed that the QQ genotype was less frequent and the $\mathrm{QR}+\mathrm{RR}$ genotype was more frequent in focal segmental glomerulosclerosis patients than in controls. The allele frequency of the SNP192 (Table 7) was also inline with their results. In addition, we observed that homozygous RR genotype was significantly higher in patients than that in controls (OR: 6.64, $p=0.005$ ) which indicates those people with SNP192 RR genotype may carry high risk of getting NS. This is also concluded by Kaur et al. ${ }^{24}$ who stated that the Q192R polymorphism in the PON1 gene may be associated with increased risk of coronary artery diseases in an Asian Indian population of atherosclerotic patients. In the present study, we selected two major SNPs (rs662 and rs854560) in the PON1 gene and the pooled analysis results indicated a significant association between (rs662) Q192R and NS. Our findings are consistent with previous results reported by Sana et al., ${ }^{25}$ Liu et al., ${ }^{26}$ and Shabana et al. ${ }^{27}$ who studied the effect of PON1 on coronary artery diseases. 


\section{CONCLUSIONS}

In our study, the presence of homozygous RR genotype of PON1 SNP 192 and MM homozygous genotype of PON1 SNP 55 were significantly higher in patients when compared with controls.

\section{ACKNOWLEDEGMENTS}

The authors would like to thank all participants, technical staff at Al-Imamain AlKadhimain Medical City, and the staff of departments where the practical part of this work has been carried out.

\section{DECLARATIONS}

\section{Authors' contributions}

Conceptualization: RJA, RSB, SHA. Data curation: RJA, RSB, SHA. Formal analysis: RJA, RSB, SHA. Funding acquisition: RJA. Investigation: RJA. Methodology: RJA, RSB, SHA. Project administration: RJA, RSB, SHA. Resources: RJA, RSB, SHA. Software: RJA, RSB, SHA. Supervision: RSB. Validation: RJA, RSB, SHA. Visualization: RJA, RSB, SHA. Writingoriginal draft: RJA. Writing-review \& editing: RJA, RSB, SHA. All authors reviewed and approved this article before publication.

\section{Conflict of interest}

There are no conflicts of interest to declare.

\section{Ethical approvals}

All procedures followed were in accordance with the ethical standards, and study protocols were approved by the Ethics Committee (Institutional Review Board). Consent was obtained at the time of enrollment by the study staff. The parents or guardians of the children were informed concerning the purpose and procedures of the study before written consent was obtained. The child's consent was obtained orally before the beginning of the evaluations.

\section{Data availability}

The data that support the findings of this study are available from the corresponding author, upon reasonable request.

\section{Funding resources}

This work didn't receive any fund. 


\section{REFERENCES}

1. Niaudet P, Boyer O. Idiopathic Nephrotic Syndrome in Children: Clinical Aspects. In: E A, W H, P N, N Y, F E, S G, et al., editors. Pediatric Nephrology. Springer, Berlin, Heidelberg; 2016. p. 839-882. Available from: 10.1007/978-3-662-43596-0_24.

2. Geary DF, Schaefer F. Comprehensive Pediatric Nephrology. Elsevier Inc.; 2008. Available from: 10.1016/B978-0-323-04883-5.X5001-6.

3. Agrawal S, Zaritsky JJ, Fornoni A, Smoyer WE. Dyslipidaemia in nephrotic syndrome: mechanisms and treatment. Nat Rev Nephrol. 2018;14(1):57-70. Available from: 10.1038/nrneph.2017.155.

4. Aviram M. Does paraoxonase play a role in susceptibility to cardiovascular disease? Mol Med Today. 1999;5(9):381-386. Available from: 10.1016/s1357-4310(99)015464.

5. Adkins S, Gan KN, Mody M, Du L, N B. Molecular basis for the polymorphic forms of human serum paraoxonase/arylesterase: glutamine or arginine at position 191, for the respective A or B allozymes. Am J Hum Genet. 1993;52:598-608.

6. Dias CG, Batuca JR, Marinho AT, Caixas U, Monteiro EC, Antunes AMM, et al. Quantification of the arylesterase activity of paraoxonase-1 in human blood. Anal Methods. 2014;6(1):289-294. Available from: 10.1039/c3ay41527a.

7. Kowalska K, Socha E, Milnerowicz H. Review: The role of paraoxonase in cardiovascular diseases. Ann Clin Lab Sci. 2015;45:226-259. 25887882.

8. Ponce-Ruiz N, Murillo-González FE, Rojas-García AE, Hernández YYB, Mackness $\mathrm{M}$, Ponce-Gallegos J, et al. Phenotypes and concentration of PON1 in cardiovascular disease: The role of nutrient intake. Nutr Metab Cardiovasc Dis. 2020;30(1):40-48. Available from: 10.1016/j.numecd.2019.08.013.

9. Ashiq S, Ashiq K, Shabana S, Shahid S, Qayyum M, Sadia H. Prevalence and role of different risk factors with emphasis on genetics in development of pathophysiology of coronary artery disease (CAD). Pakistan Hear J. 2020;52:279-287.

10. Shahsavari G, Nouryazdan N, Adibhesami G, Birjandi M. Genetic associations and serum paraoxonase levels with atherosclerosis in western Iranian patients. Mol Biol Rep. 2020;47(7):5137-5144. Available from: 10.1007/s11033-020-05585-2.

11. Erlich HA. PCR Technology. In: Erlich HA, et al., editors. PCR Technology: Principles and Applications for DNA Amplification. London, Palgrave Macmillan UK; 1989. Available from: 10.1007/978-1-349-20235-5.

12. Sambrook J, Fritsch EF, Maniatis T. Molecular Cloning: A Laboratory Manual. Vols. $1989 ; 1$.

13. Abramson JH. WINPEPI updated: computer programs for epidemiologists, and their teaching potential. Epidemiol Perspect Innov. 2011;8(1):1-1. Available from: 10.1186/1742-5573-8- 1 .

14. IBM SPSS Statistics 26; 2019. Available from: https://www.ibm.com/support/pages/ downloading-ibm-spss-statistics-26.

15. McMurran SL. The Hardy-Weinberg Principle. PRIMUS. 2010;20(6):529-549. Available from: 10.1080/10511970.2010.489544. 
16. Frishberg Y, Toledano H, Becker-Cohen R, Feigin E, Halle D. Genetic polymorphism in paraoxonase is a risk factor for childhood focal segmental glomerulosclerosis. Am J Kidney Dis. 2000;36(6):1253-1261. Available from: 10.1053/ajkd.2000.19842.

17. Furlong CE, Richter RJ, Seidel SL, Motulsky AG. Role of genetic polymorphism of human plasma paraoxonase/arylesterase in hydrolysis of the insecticide metabolites chlorpyrifos oxon and paraoxon. Am J Hum Genet. 1988;43:230-238.

18. Furlong CE, Suzuki SM, Stevens RC, Marsillach J, Richter RJ, Jarvik GP, et al. Human PON1, a biomarker of risk of disease and exposure. Chem Biol Interact. 2010;187(13):355-361. Available from: 10.1016/j.cbi.2010.03.033.

19. Guijarro C, Keane WF. Lipid-Induced Glomerular Injury. Nephron. 1994;67(1):1-6. Available from: 10.1159/000187881.

20. Hassett C, Richter RJ, Humbert R, Chapline C, Crabb JW, Omiecinski CJ, et al. Characterization of cDNA clones encoding rabbit and human serum paraoxonase: the mature protein retains its signal sequence. Biochemistry. 1991;30(42):10141-10149. Available from: 10.1021/bi00106a010.

21. Humbert R, Adler DA, Disteche CM, Hassett C, Omiecinski CJ, Furlong CE. The molecular basis of the human serum paraoxonase activity polymorphism. Nat Genet. 1993;3(1):73-76. Available from: 10.1038/ng0193-73.

22. Mackness MI, Arrol S, Durrington PN. Paraoxonase prevents accumulation of lipoperoxides in low-density lipoprotein. FEBS Letters. 1991;286(1-2):152-154. Available from: 10.1016/0014-5793(91)80962-3.

23. Biyikli NK, Alpay H, Yildiz N, Agachan B, Ergen A, Zeybek U, et al. Paraoxonase 1 192 and 55 polymorphisms in nephrotic children. Pediatr Nephrol. 2006;21(5):649654. Available from: 10.1007/s00467-006-0073-y.

24. Kaur S, Bhatti GK, Vijayvergiya R, Singh P, Mastana SS, Tewari R, et al. Paraoxonase 1 Gene Polymorphisms (Q192R and L55M) Are Associated with Coronary Artery Disease Susceptibility in Asian Indians. Int J Diabetes Metab. 2018;38:38-47. Available from: 10.1159/000494508.

25. Ashiq S, Ashiq K. The Role of Paraoxonase 1 (PON1) Gene Polymorphisms in Coronary Artery Disease: A Systematic Review and Meta-Analysis. Biochem Genet. 2021;59(4):919-939. Available from: 10.1007/s10528-021-10043-0.

26. Liu T, Zhang X, Zhang J, Liang Z, Cai W, Huang M, et al. Association between PON1 rs662 polymorphism and coronary artery disease. Eur J Clin Nutr. 2014;68(9):10291035. Available from: 10.1038/ejcn.2014.105.

27. Shabana NA, Ashiq S, Ijaz A, Khalid F, ul Saadat I, Khan K, et al. Genetic risk score (GRS) constructed from polymorphisms in the PON1, IL-6, ITGB3, and ALDH2 genes is associated with the risk of coronary artery disease in Pakistani subjects. Lipids Health Dis. 2018;17(1). Available from: 10.1186/s12944-018-0874-6. 